\title{
THE TRAITE DES TROIS IMPOSTEURS: A PHILOSOPHICAL PLOT, OR (RE)TRANSLATION AS STRATEGY OF ENLIGHTENMENT
}

\author{
Sonja Lavaert ${ }^{1}$ \\ 1 Vrije Universiteit, Brussel, Belgium
}

\begin{abstract}
This contribution focuses on the complex origin and publication history of the clandestine treatise Traité des trois imposteurs that put into motion the process of the radical Enlightenment. The treatise consists almost completely of a compilation of paraphrases and quotations of heterodox texts of the $17^{\text {th }}$ century. A summary will be made of the most important source texts assembled in the collage. One of them is Vanini's De Admirandis Naturae Reginae Deaeque Mortalium Arcanis from 1619 on which the analysis will focus. Two editions of the treatise are particularly important in this respect and will be looked at in detail: the first publication in print from 1719 under the title L'esprit de Spinosa (that can be seen as a translation in French) and the re-edition as Traité des trois imposteurs from 1768 probably made by D'Holbach (considered as a retranslation in French). The hypothesis developed of this contribution is that through the translation and the retranslation, step by step, a shift in meaning from Renaissance pantheism and the idea of natural religion to atheism and materialism took place. This hypothesis will be assessed by a precise comparative analysis of two excerpts of Dialogue 50 of De Admirandis, the French translation in L'Esprit de Spinosa and the French retranslation in the Traité des trois imposteurs. Finally, also the Italian translation of 1798 will be compared with the previous editions/ translations.
\end{abstract}

Keywords: Clandestine philosophy; Radical Enlightenment; Radicalisation and Enlightenment through translation and retranslation 


\title{
O TRATADO DOS TRÊS IMPOSTORES: UM ENREDO FILOSÓFICO, OU A (RE)TRADUÇÃO COMO ESTRATÉGIA DO ILUMINISMO
}

\begin{abstract}
Resumo: O artigo enfoca a complexa origem e o histórico de publicação do tratado clandestino Traité des trois imposteurs [Tratado dos três impostores] que põe em ação o processo o Iluminismo radical. O tratado é composto quase exclusivamente por uma compilação de paráfrases e citações de textos heterodoxos do século XVII. Apresenta-se um resumo das mais importantes fontes coligidas na colagem. Uma delas é De Admirandis Naturae Reginae Deaeque Mortalium Arcanis [Dos admiráveis mistérios da Natureza, rainha e deusa dos mortais] de Giulio Cesare Vanini (1619), na qual se centra a presente análise. Duas edições do tratado são aqui particularmente importantes, e serão examinadas detalhadamente: a primeira publicação impressa (1719), sob o título L'esprit de Spinosa [O espírito de Spinoza] (que pode ser vista como uma tradução para o francês) e a reedição como Traité des trois imposteurs (1768), provavelmente por D'Holbach (tomada como retradução para o francês). A hipótese desenvolvida aqui é a de que, através da tradução e da retradução, passo a passo, ocorreu uma mudança de significado, do panteísmo renascentista e da ideia de religião natural para o ateísmo e o materialismo. Essa hipótese é avaliada por uma análise comparativa precisa de dois excertos do Diálogo 50 de De Admirandis, da tradução francesa em L'Esprit de Sponsa e da retradução francesa em Traité des trois imposteurs. Finalmente, a tradução italiana de 1798 será comparada às edições/traduções anteriores.
\end{abstract}

Palavras-chave: Filosofia clandestina; Iluminismo radical; Radicalização e Iluminismo através da tradução e da retradução

1.

We cannot speak but in superlative terms about the most subversive Traité des trois imposteurs that put into motion the process of the radical Enlightenment. ${ }^{1}$ Its origin and author are a

${ }^{1}$ The modern editions of Schröder (1992, bilingual, with a German translation) and Berti (1994) are both accurate and provided with an introduction, a commentary,

Cad. Trad., Florianópolis, v. 39, nº 1, p. 73-93, jan-abr, 2019. 
complete mystery. It was the most famous and the most circulated clandestine treatise ever, published several times all over the $18^{\text {th }}$ century, circulated by manuscripts, and translated in Latin, Italian and German still by the end of that revolutionary century. The rupture it made with the tradition dominated by Christian hegemony can only be called radical: the Traité deconstructed and neutralized the idea of God, it demolished the doctrine of creation and divine providence, it eliminated the authority of revelation and miracles, it brought the fear of punishment to an end, it delegitimised the political power of ecclesiastics and the social hierarchy established by God. Moreover, the critique of religion and metaphysics was related to the unmasking of the political agenda of the established authorities, and this explosive cocktail was presented in a language comprehensible for everyone. It represented a radical rupture with the tradition and attacked all illusion, legends and myth, but it was not completely new; it rested on, or at least it was closely related to a long-running legend, a common knowledge, namely the topos of the imposture of religion (Paganini 72). We find the earliest literary testimony of this topos of fraud by the three monotheistic religions in the papal bull of 1239 against Frederick II who would have said 'that the whole world is deceived by three impostors: Moses, Jesus and Mohamed'. Although he did not assert anything of the sort or we do not find textual testimony of it, the Islamic philosopher Averroes was accused of having launched the idea of the three impostors and this rumour took on a life of its own. From the rumours arose the legend that a book 'On the three impostors' existed. Once the legend was launched various presumed authors were put forward, such as Piero della Vigna, the secretary of Frederick II, Pietro Aretino, Vanini, Machiavelli, Boccaccio, and so on (Schröder, xiii).

an extensive bibliography, notes and index; in the edition of Schröder in addition are provided the different text variants of the editions of 1719, 1768 and 1777. For further reading and analyses, see the work of Benitez, Berti, Charles-Daubert, Israel, Paganini, Schröder, and Vernière.

Cad. Trad., Florianópolis, v. 39, n $^{0}$ 1, p. 73-93, jan-abr, 2019. 
At present two books with this title exist: the Latin De tribus impostoribus and the French Traité des trois imposteurs. Both of them were written in the late $17^{\text {th }}$ century independently of one another. I will focus on the French text in this paper. There are two different versions of it: the earlier version entitled Esprit de Spinosa printed in 1719, and a later version, Traité des trois imposteurs published in 1768. As we do not know who wrote the first mother version of the text, and subsequently we do not have certainty on when and where it was written, I will briefly discuss the dating of the first edition. The Esprit/Traité presents itself as a compilation or even patchwork of translated and paraphrased fragments of heterodox texts of the $17^{\text {th }}$ century. I will first give an overview of the source texts assembled in the treatise. Then I will focus on one source author, Giulio Cesare Vanini from whose De Admirandis Naturae Reginae Deaeque Mortalium Arcanis (On the Marvellous Secrets of Nature, the Queen and Goddess of Mortals) from 1616 several paraphrases and translations into French appear first in the Esprit, then in the retranslated Traité, and I will concentrate on two of these fragments. Finally, I will compare the anonymous Italian translation of the Traité from 1798 with the source text of Vanini. Departing from this case study I want to sustain the twofold thesis that 1) the new and radically subversive ideas were widely disseminated making of translation an essential part of the philosophical programme, and 2) through translation and retranslation the philosophical messages underwent a significant change and were transformed in the direction of a radical Enlightenment.

Let me come back to the (a bit complicated) story of our text. The earliest version has the title Esprit de Spinosa. It was first published in The Hague in 1719. The French Huguenot journalist Lucas is named as a possible author (Schröder xxvii). However, 
the book circulated as a manuscript before 1719; in the collection of the Baron of Hohendorf who died in 1719 a manuscript was found. The oldest reliable attestation of the existence of the text dates from January 1700. Furthermore, the presence of fragments paraphrased and translated from Spinoza's Opera posthuma indicates that the Esprit was not composed at an earlier date than $1678 .^{2}$ After a translation in Latin (1721) the text was republished in French in 1768 in Amsterdam, under the title Traité des trois imposteurs, an edition commonly assigned to the Baron D'Holbach. After this publication, the fame of the treatise grew steadily with six subsequent editions that followed before 1798 .

The composition of the Traité is extremely complex. It consists almost completely of a compilation of paraphrases and quotations of fragments of different heterodox texts of the late $17^{\text {th }}$ century: by Spinoza (mainly the Ethics and Theological-Political Treatise), Hobbes (the Latin edition of the Leviathan), the sceptic François La Mothe le Vayer, and the atomistic materialist Guillaume Lamy. It also contains a series of earlier heterodox texts: of Vanini, and via Vanini's paraphrases and reformulations, of Machiavelli. Well-chosen long quotations appropriated in silence (the sources are mostly not mentioned) are alternated with comments of the anonymous author and strategically inserted and appropriated into a clearly legible combative manifesto.

The Esprit/Traité brings together excerpts of the mentioned authors wherein the church as power institution, the revealed religion, the traditional metaphysics and the political impact of all these factors are criticized. The attack on ecclesiastical power and religion is crucial. Its most important novelty although is that it offers theoretical text fragments of different heterodox authors in one coherent text, that it relates them to their political significance

2 The main argument on which Schröder in his introduction is relying for this dating: the text cannot be elder considering the paraphrases from and textual similarities with Spinoza's Ethica, and a letter (letter 73 to Oldenburg) published in the Opera posthuma of 1677 (xvii).

Cad. Trad., Florianópolis, v. 39, nº 1, p. 73-93, jan-abr, 2019. 
and that it presents them in common sense language. It translates moreover the whole new constructed text into the vernacular French, a language comprehensible for a broad and common readership.

\section{3.}

For the comparative analysis, I have chosen a passage of the treatise that can be considered as a translation of a fragment of Vanini's De admirandis. It occurs in both versions with slight but interesting differences. Lucilio alias Giulio Cesare Vanini was an Italian philosopher and freethinker, one of the first naturalists and representatives of libertinism. His De admirandis is composed of dialogues taking place between the author-philosopher and an imaginary Alessandro. Vanini interprets religion in a naturalistic way, and regarding the motif of fraud by religion he closely aligns with Machiavelli whose work at first sight he reads through the commonplace lenses of the Christian countermovement as the consultant of tyrants, cynical advocate of violence and fraud. ${ }^{3}$ In reality, however, Vanini uses tropes such as metonymy, litotes and irony and he thereby completely changes the interpretation: Machiavelli does not advise to despotic princes how to use religion for their political purposes, but he demonstrates that religion by nature is political and fictional. The revolutionary rhetoric, however, was quickly noticed and the establishment took drastic measures: in 1619 Vanini was executed in a horrific manner, and together with his books he was burned. Furthermore, texts were published in which his atheism was confuted. Vanini did not only focus on religion as fiction and deception, but he also criticized politics that instead of aiming at the common welfare relies on coercion and repression of "the humble people who are always

3 The image of Machiavelli as the consultant of tyrants is forged by his critics and his opponents, i.e. the priests and the princes, as I argue in the text 'Niccolò Machiavelli. The logic of conflict, against the logic of war'.

Cad. Trad., Florianópolis, v. 39, nº 1, p. 73-93, jan-abr, 2019. 
prepared to let themselves deceive under the pressure of its duties and slavery". ${ }^{4}$ (Vanini 330) There can be no doubt that Vanini spoke the truth in the presence of the thousand men when he was conducted to the stake on place du Salin in Toulouse, and that he revealed thereby his real intentions:

\begin{abstract}
There is neither God nor Devil, for was there a God, I would intreat him to consume the Parliament with his Thunder, as being altogether unjust and wicked; and was there a Devil, I would also pray to him to swallow it up in some subterraneous Place. But since there is neither the one nor the other, I cannot do it. (Durand 93)
\end{abstract}

In the following analysis, I consider the text of Vanini, a paragraph of Book IV, Dialogue $50^{5}$ as the source-text, the anonymous Esprit from 1719 as a translation, and the Traité from 1768 edited by D'Holbach as a retranslation. ${ }^{6}$ In 1717 - same period as the Esprit was first published and manuscripts (as the one mentioned) were circulating in Holland - the historian David Durand published La vie et les sentimens de Lucilio Vanini, and he cited some passages of Vanini's work, i.a. the paragraph that I will discuss, in a French translation made by himself. It is useful

\footnotetext{
${ }^{4}$ This is how Vanini expresses it in his introduction to the Amphitheatrum aeternae providentiae (1615): "[...] ad illas profligandas excindendasque omnes animi et corporis adhibent machinationes."

${ }^{5}$ In Book IV, Dialogue 50 of the De Admirandis naturae Vanini (I.C.) is discussing with his interlocutors about the nature of God (De Deo) as it is seen by the pagan religions; see in the modern bilingual edition (with Italian translation) of Raimondi: 1342-1365.

${ }^{6}$ It will be clear from my analysis that the edition of 1768 (probably made by D'Holbach) is not simply a re-edition but it is a retranslation. For the differences and/or the thin line between re-editions and retranslation, see Koskinen and Paloposki 294-298. For a study on the use by D'Holbach of translation as a revolutionary philosophical programme (although reflections on the Traité are missing), see Kozul. On retranslation, see also the articles of Venuti and Brisset.
} 
for this occasion to also present this, as it were 'innocent' French translation made by a historian who was not a heterodox author and so who cannot be suspected of having intended to spread the voice of naturalism or materialism.

Let us first have a look at the first two text fragments. I quote the passages of Vanini in Latin followed by my back translation in English (V1), the translation of Durand in French and its translation in English ${ }^{7}$ (D1), and the translation in French of the Esprit de Spinosa III, §2 followed again by my back translation in English (E1). ${ }^{8}$ The last text fragment is the retranslation in French of the Traité des trois imposteurs II, $\S 11$ followed by my back translation in English (T1). ${ }^{9}$

V1.

"In unica Naturae lege, quam ipsa Natura, quae Deus est (est enim principium motus) in omnium Gentium animis inscripsit. Caeteras vero leges non nisi figmenta et illusiones esse asserebant, non a Cacodaemone aliquo inductas (fabulosum namque illorum genus dicitur a Philosophis), sed a Principibus ad subditorum paedagogiam excogitatas et a sacrificulis, ob honoris et auri aucupium, confirmatas,

\footnotetext{
${ }^{7}$ In 1730 a translation in English has been published under the title : The Life of Lucilio (alias Julius Caesar) Vanini, Burnt for Atheism at Thoulouse \& $c$.

${ }^{8}$ For the text of the Esprit de Spinosa I quote from the original edition, La vie et L'Esprit de Mr. Benoit de Spinosa of 1719 of which is preserved a copy in the Library UB of Frankfurt (Sign.: 703), III §2: 74-80. There is also a copy of this 1719-edition in the Royal Library of Brussels (sign.: II 86730) and in the UCLA-Library at Los Angeles. The copy in Halle mentioned by Van der Linde in the Spinoza. Bibliographie of 1871 (31) has disappeared. See: Schröder, Traktat/ Traité, n33, xxii; Vercruysse, "Bibliographie descriptive des éditions du Traité des trois imposteurs", 65-67; Charles-Daubert, "L'image de Spinoza dans la littérature clandestine', 68.

${ }^{9}$ For the text of the Traite des trois imposteurs, I quote from the modern bilingual edition made by Schröder, Traktat über die drei Betrrüger / Traité des trois imposteurs (L'esprit de Mr. Benoit de Spinosa) that furnishes the text from the 1768-edition with in notes the variations of the edition of 1777 (and of 1719).
} 
non miraculis, sed Scriptura, cuius nec originale ullibi adinvenitur, quae miracula facta recitet et bonarum ac malarum actionum repromissiones polliceatur, in futura vita, ne fraus detegi possit." (De admirandis naturae IV, $50,1362)$

"In the religion of nature only, since nature itself, which is God, insofar it is the principle of movement impressed in the soul of all men. All other religions, according to those ancient Sages, were but Illusions, not forged by any good or evil spirits, (for they believed such beings belonged to the reign of fables) but by princes and magistrates, in order to curb their people; and fomented by ambitious and covetous priests, which, instead of true and real miracles, to confirm its veracity, made use of certain scriptures, the originals of which the rewards and punishments regard but another life, fearing that the fraud should be too early discovered."

D1.

"Dans la seule Religion de la Nature, dit Vanini, que la Nature meme, qui est Dieu, puisque'elle est le principe du movement, a gravé dans l'ame de tous les Hommes. Toutes les autres Religions, selon ces Anciens Sages, n'étoient que des illusions, forgées non par quelque Genie bon ou mauvais (car ils s'en moquoient), mais par les Princes \& les Magistrats, pour tenir en bride les Peuples; \& fomentées par les Prêtres ambitieux ou avares, qui au lieu de vrais miracles pour les confirmer, n'y employoient qu'une Ecriture, dont l'original ne se trouve nulle part \& dont les promesses \& les menaces ne regardent que la vie à venir, depeur que la fraude ne se découvre dès ici-bas." (La vie et les sentimens de Lucilio Vanini, 126-27)

"In the Religion of Nature only, (replies Vanini) which Nature is itself that God, since it only is the Origin of Motion impress'd in the Souls of all Men. All other Religions, according to those antient Sages, were but Illusions, not 
forg'd by any good or evil Genius's, (for they never believ'd there were any such Beings) but by Princes and Magistrates, in order to curb their People; and fomented by ambitious and covetous Priests, which, instead of true and real Miracles, to confirm its Veracity, made use of certain Scriptures, the Originals of which are nowhere to be found; and of which the Rewards and Punishments regard but another Life, fearing that the Imposture shou'd be too early discover'd." (The Life of Lucilio (alias Julius Caesar) Vanini, 61)

E1.

"Oui, telle est la Folie \& la stupidité des Chrétiens, qu'ils aiment mieux passer leur Vie à idolatrer un Livre, qu'ils tiennent d'un Peuple ignorant, un Livre, où il n'y a ni ordre, ni méthodologie, que personne n'entend, tant il est confus \& mal conceu, \& qui ne sert qu'à fomenter les Divisions entre eux, telle est, dis-je, leur Folie, qu'ils aiment mieux adorer ce Phantôme, que d'écouter la Loy naturelle, que Dieu, c'est à dire la nature, entant qu'elle est le principe du Mouvement, a écritte dans le Cœur des Hommes. Toutes les autres Loyx ne sont que des fictions humaines, \& de pures illusions forgées, non par les Démons, ou par les mauvais Esprits, qui ne furent jamais qu'en idée, mais par l'adresse des Princes \& des Ecclésiastiques, ceux là, pour donner plus de poids à leur Authorité, ceux cy, pour s'enrichir par le débit d'une infinite de Chiméres, qu'ils vendent cher aux Ignorans.” (Esprit de Spinosa III, §2, 78-79)

"This is the Madness and Stupidity of the Christians that prefer to pass their life deifying a book received from an ignorant people, in which there is no order or method, that nobody understands, that is so confused and bad written, and whose only merit is to have fomented mutual dissensions, a Madness: they prefer to admire this Phantom instead of listening to the natural law which God, that is Nature, insofar it is the principle of movement, has written in the 
heart of men. All other laws are only human fictions and mere illusions forged not by Demons or evil Spirits, which only existed as an idea, but by the Princes and Priests, the first ones to give more weight to their authority, the latter to enrich themselves through an infinity of fantasies sold dearly to the ignorant."

T1.

"Les Juifs \& les Chrétiens, aiment mieux consulter ce grimoire que d'écouter la loi naturelle que Dieu, c'està-dire la Nature, en tant qu'elle est le principe de toutes choses, a écrit dans le cœur des hommes. Toutes les autres loix ne sont que des fictions humaines, \& de pures illusions mises au jour, non par les Démons ou mauvais Esprits, qui n'existerent jamais qu'en idée, mais par la politique des Princes \& des Prêtres. Les premiers ont voulu par-là donner plus de poids à leur autorité, \& ceux-ci ont voulu s'enrichir par le débit d'une infinité de chimeres qu'ils vendent cher aux ignorans." (Traité des trois imposteurs II, §11, 40)

"The Jews and Christians prefer to consult this grimoire instead of listening to the law of nature which God, that is nature, insofar it is the principle of all things, has written in the heart of all men. All other laws are but human fictions and mere illusions invented, not by Demons or evil Spirits, which only existed as an idea, but by the politics of Princes and Priests. The first ones thereby wanted to give more weight to their authority, the latter wanted to enrich themselves through an infinity of fantasies sold dearly to the ignorant."

Regarding their essential parts, one can clearly speak about a translation and not a paraphrase, although there is a series of farreaching shifts. The key formula in Vanini, "Nature itself, which is God, insofar it is the principle of movement impressed in the soul of all Men" ("ipsa Natura, quae Deus est (est enim principium 
motus) in omnium Gentium animis inscripsit") becomes in the Esprit: "la Loy naturelle, que Dieu, c'est à dire la nature, entant qu'elle est le principe du Mouvement, a écritte dans le Cœur des Hommes" ("the natural law that God, that is Nature, insofar it is the principle of movement, has written in the heart of men"). We see a transformation which is not unimportant, a reversal, within this overall accurate translation. In the text of Vanini the phrase "Nature itself, which is God" can perhaps be read in a nonnaturalistic (or non-materialistic) way, while the reversal "God, that is Nature" can only be understood within the framework of naturalism. In both texts nature is "the principle of movement", and the law of nature is belonging to the inner being of all people: in the case of Vanini it is forged in the "soul", in the Esprit in the "heart". All other "religions" by Vanini, "laws" in the Esprit, are "fictions" and "illusions" whereby the Esprit adds that these are "human", which obviously is exactly the same as what we read in both fragments: they have "not been introduced by evil Spirits" - of which Vanini and the philosophers think that their existence "belongs to the reign of fables", while according to the Esprit they only exist "as an idea" - but they are invented by "princes" and "priests" who in this way increase their political power and richness to the detriment of the ignorant multitude, the nationals, the common people. This motif is equally present in both texts but shifted over different sentences.

When we now compare the text of the Traite des trois imposteurs from 1768 (T1) with the text of the Esprit de Spinosa from 1719 (E1), we observe only one small shift in the discussed passage: the nature is "the principle of all things". This seems to be a more precise wording compared to "of the movement" and it aligns seamlessly to the simple and even banal (not philosophical) wordings of D'Holbach in his major work, the Système de la nature (1770), but also to its materialism. One observes a more significant shift between the two texts in the references to the Bible. The Esprit says about the "Christians" in a long and rich phrase that they "prefer to pass their life deifying a book received 
from an ignorant people [allusion to the Jews] in which there is no order or method, that nobody understands, that is so confused and bad written, and whose only merit is to have fomented mutual dissensions, a madness". The Traité immediately puts the "Jews and Christians" together on one line and says that they simply "prefer to consult this grimoire": an omission that strengthens the message. It is significant that in both varieties the word "fraud" of Vanini's text is omitted and replaced by "fantasies" sold to the ignorant by the "princes and priests".

We now compare a second passage from the three texts: still from Dialogue 50 of De admirandis naturae (V2), of which we find the translation in Esprit de Spinosa XVIII, §2 (E2) and the retranslation in Traité des trois imposteurs IV, §2 (T2). ${ }^{10}$

V2.

"Deus simplex est, nulla igitur in eo distinctio ; que de re nulla erit in eo causarum comparatio. Neque homo est inquiunt - propter Deum. Nullius indigus Deus est." (De admirandis naturae IV, 50, 1344)

"God is simple, there is not one distinction in him and therefore no causal relation at all. Neither do men exist in function of God, say [the philosophers]: God does not need anything."

E2.

"Dieu est un Etre simple, ou une Extension infinie, qui ressemble à ce qu'il contient, c'est-à-dire qui est matériel, sans être néanmoins ni juste, ni miséricordieux, ni jaloux ni rien de ce qu'on s'imagine, \& qui par conséquent n'est ni Punisseur, ni Rémunérateur." (Esprit de Spinosa XVIII, $\S 2,184-185)$

${ }^{10}$ In the mentioned edition of L'Esprit de Mr. Benoit de Spinosa (1719): 184-185 and in the modern edition by Schröder of the Traité des trois imposteurs (1992): 112.

Cad. Trad., Florianópolis, v. 39, n $^{0}$ 1, p. 73-93, jan-abr, 2019. 
"God is a simple Being, of infinite extent, that resembles what it contains, in other words that is physical, without however being just, compassionate, jealous or anything of the sort imagined, and therefore he is neither Punishing or Rewarding."

T2.

"Dieu n'étant, comme on a vu, que la nature, ou, si l'on veut, l'assemblage de tous les êtres, de toutes les propriétés \& non distincte de ses effets; il ne peut être appellé ni bon, ni méchant, ni juste, ni miséricordieux, ni jaloux; ce sont des qualités qui ne conviennent qu'à l'homme; par conséquent il ne sauroit ni punir ni récompenser." (Traité des trois imposteurs IV, §2, 112)

"God is nothing else than nature, as we saw, or, in other words, the assembly of all the things, of all the features, and not distinguishable from its effects; he cannot be called good or bad, just or compassionate or jealous; these are qualities suiting only with human beings; therefore, he cannot neither punish or reward."

In the retranslation of D'Holbach the phrase that breathes the spirit of Spinoza is omitted: "a simple being, of infinite extent, that resembles what it contains, in other words that is physical" is replaced by a much clearer phrase, furthermore a repetition: "God is nothing else than nature". The otherwise explicit "that is physical" from the Esprit is replaced in the Traité by a quasiexplanation which refers to how to understand this formula: "the assembly of all the things, of all the features, and [that is] not distinguishable from its effects". In Vanini's text we find a phrase that renders the same idea and that is partly translated in both the fragments of 1719 and 1768, an idea situated midway between Spinoza and D'Holbach: "God is simple, there is not one distinction in him and therefore no causal relation at all". 
Another transformation in the text of 1768 with respect to the 1719 version is: the features of God include that "he cannot be called good or bad", which further is explained by since these are "qualities suiting only with human beings".

The Renaissance pantheism and the idea of natural religion in the case of Vanini are really transformed into clear materialism, in other words, atheism in the case of the Traité by D'Holbach. Although he was himself a major figure of the Enlightenment, Voltaire was so shocked by and concerned about the potential influence of atheism of the Traité that he published against it the Épitre à l'auteur du livre des trois imposteurs (1769); it is in this Épitre that we read the often-quoted phrase "Si Dieu n'existait pas, il faudrait l'inventer". ${ }^{11}$ Of course, within the framework of this article it is not possible to present sufficient text fragments, but let this analysis be illustrative. The Bible criticism and the religion criticism of Vanini is first translated, domesticated and incorporated to the Esprit, then retranslated, domesticated and incorporated to the Traité. The religion criticism turned into a radically new philosophy, an operation to which the translation and the retranslation are used as a strategy.

\section{4.}

As already said the circulation of the Traité also occurred by means of translations in Latin and in modern European languages. In 1787 a German translation of the Esprit was published in Berlin with the enigmatic title Spinoza II. oder Subiroth Sopim. This translation was made in 1745 by one of the most radical freethinkers of the era, Johann Christian Edelmann. This Hebrew-like title is an anagram of the Latin word 'impostoribus'.

An anonymous Italian translation of the retranslated Traité published by D'Holbach appeared in 1798: Il celebre e raro

${ }^{11}$ Voltaire, Euvres complètes, Vol. 10, Paris, 1877, 402-405. 
trattato de' tre impostori. To conclude I'll have a look to this Italian translation comparing it with the text of Vanini which in a certain sense hereby comes home. Between 1796 and 1799 the north of Italy was deeply influenced by the French revolutionary spirit and feverish efforts were made to carry out political and religious innovations. These innovations were aimed at the Enlightenment of society and to create the intellectual fertile setting for establishing a democratic republican regime. It was the making of a revolution of the mind, a philosophical plot. And it is in this context that also the anonymous translation must be situated.

When we have a look at how the two previously analysed passages in Vanini's De Admirandis naturae (V1\&2) and in the Traité des trois imposteurs (T1\&2) are rendered in the Il celebre e raro trattato de' tre impostori, 1798, II, $\$ 11$ ( $\left.\mathrm{T}_{\mathrm{it}} 1 \& 2\right)$, we find a nearly 'perfect', faithful and literal translation of D'Holbach's Traité-text, with almost no shifts.

$\mathrm{T}_{\mathrm{it}} 1$.

"I giudei e i cristiani amano meglio di consultare questo libro magico che d'ascoltare la legge naturale scolpita nel cuore degli uomini da Dio, vale a dire dalla natura siccome principio d'ogni cosa. Tutte le altre leggi non sono che umane finzioni e pure illusioni poste alla luce non da' demoni o spiriti maligni, che non esistettero mai se non nella immaginazione, ma dalla politica de' tiranni e de' preti. I primi hanno con ciò voluto dar maggior peso alla loro autorità, e questi arrichirsi collo spacciare un'infinità di chimere che vendono care agli ignoranti." (Il celebre $e$ raro trattato de' tre impostori, 50-51)

"The Jews and Christians prefer to consult this grimoire instead of listening to the law of nature which God, that is nature, insofar it is the principle of all things, has written in the heart of all men. All other laws are but human fictions and mere illusions invented, not by demons or evil spirits, 
which only existed in our imagination, but by the politics of tyrants and priests. The first ones thereby wanted to give more weight to their authority, the latter wanted to enrich themselves through an infinity of fantasies sold dearly to the ignorant."

$\mathrm{T}_{\mathrm{it}} 2$.

"Dio non essendo, siccome veduto abbiamo, che la natura, $\mathrm{o}$, se si vuole, l'unione di tutti gli esseri, di tutte le proprietà e di tutte le energie, necessariamente è la causa immediata e non distinta de' suoi effetti; egli non può essere chiamato né buono né cattivo, né giusto né misericordioso né geloso; queste sono qualità le quali non convengono se non all"uomo; per conseguente egli non saprebbe né punire né ricompensare." (Il celebre e raro trattato de' tre impostori, 72 )

"God being nothing else than nature, as we saw, or, in other words, the union of all beings, of all features and of all energies, is necessarily the immanent cause that is not distinguishable from its effects; he cannot be called good or bad, just or compassionate or jealous; these are qualities suiting only with human beings; therefore, he cannot neither punish or reward."

Compared to the version of Vanini's Dialogue 50 of the $D e$ Admirandis naturae we can repeat everything we have already noticed: "ipsa Natura, quae Deus est" ("Nature itself, which is God") has become "Dio, vale a dire la natura" ("God, that is nature"), "principium motus" ("the principle of movement") changed into "principio d'ogni cosa" ("the principle of everything"), or as it is expressed in the second fragment: "God being nothing else than nature, $[\ldots]$ or, in other words, the union of all beings, of all features and of all energies, is necessarily the immanent cause that is not distinguishable from its effects". This is a translation with few shifts inspired only by Italian grammar. Nevertheless, there is one addition, "the immanent cause", that repeats the sense of the 
words "not distinguishable of its effects" and thereby intensifies and insists in the new materialistic thought.

The Italian translation consolidates the shift in meaning that first occurred between the Latin source-text of Vanini and its French translation in the Esprit and then occurred between the Esprit and the retranslation in the Traité. These (re)translations step by step radicalize the (philosophical) meaning of the text and transform the ideas of natural religion into materialism and the metaphysical critique into political revolutionary ideas. I can therefore conclude by stressing again what I said at the beginning of this article. The Traité des trois imposteurs made a radical rupture with tradition: in terms of content, i.e. the critique of religion and metaphysics, the materialism and the atheism that unmask the political agenda of the oppressors, exploiters and tyrants, and by writing this content in a language comprehensible for everyone. These new ideas were widely spread making of translation an essential part of the philosophical programme. In addition, it was through translation itself that the meanings transformed themselves into their radical novelty and Enlightenment.

\section{References}

\section{Primary Sources}

Anonymus. La vie et l'esprit de Mr. Benoit de Spinoza. S.1.: s.n., 1719.

Traité des trois imposteurs. Yverdon, de l'imprimerie du Professeur de Felice [Amsterdam], 1768.

. Traité des trois imposteurs. S.1.: s.n., 1777.

Cad. Trad., Florianópolis, v. 39, nº 1, p. 73-93, jan-abr, 2019. 
. Traktat über die drei Betrüger. Traité des trois imposteurs (L'esprit de Mr. Benoit de Spinosa). Kritisch herausgegeben, übersetzt, kommentiert und mit einer Einleitung versehen von W. Schröder. Hamburg: Felix Meiner Verlag, 1992.

. Trattato dei tre impostori. La vita e lo spirito del signor Benedetto de $\overline{S p i n o z a}$. A cura di S. Berti. Prefazione di Richard H. Popkin. Torino: Einaudi, 1994.

. Il celebre e raro trattato de' tre impostori 1798. A cura di L. Guerci. Torino: Edizioni dell'Orso, 1996.

. Spinoza II. oder Subiroth Sopim. Rom, bey der Wittwe Bona Spes 5770. [Berlin, 1787?].

Durand, D. La vie et les sentimens de Lucilio Vanini. Rotterdam: Gaspar Fritsch, 1717.

. The Life of Lucilio (alias Julius Caesar) Vanini, Burnt for Atheism at Thoulouse \&c. London: s.n., 1730.

Vanini, G. C. De admirandis naturae reginae Deaeque Mortalium Arcanis (I meravigliosi segreti della natura, regina e dea dei mortali, 1616. Tutte le opere. A cura di P. Raimondi. Milano: Bompiani, 2010.

. Amphitheatrum aeternae providentiae (Anfiteatro dell'eterna provvidenza), 1615. Tutte le opere. A cura di P. Raimondi. Milano: Bompiani, 2010.

Voltaire. Épitre à l'auteur du livre des trois imposteurs (1769). Oeuvres complètes. Vol. 10. Paris, 1877. 402-405.

\section{Secondary Literature}

Benitez, M. La Face cachée des Lumières. Recherches sur les manuscrits philosophiques clandestins de l'âge classique. Paris / Oxford: Universitas / Voltaire Foundation, 1996. 
Berti, S., Charles-Daubert, F. and Popkin, R. H. (eds.). Heterodoxy, Spinozism, and Free Thought in Early-Eightheen-Century Europe. Studies on the Traité des trois imposteurs. Dordrecht / Boston / London: Kluwer Academic Publishers, 1996.

Brisset, A. "Retraduire ou le corps changeant de la connaissance. Sur l'historicité de la traduction". Palimpsestes 15, 2004. p. 39-67.

Charles-Daubert, F. "Les Traités des trois imposteurs aux XVIIe et XVIIIe siècles". Canziani, G. (ed.). Filosofia e religione nella letteratura clandestina. Secoli XVII e XVIII. Milano: FrancoAngeli, 1994. p. 291-336.

Israel, J. Radical Enlightenment. Philosophy and the Making of Modernity 16501750. Oxford: Oxford University Press, 2001.

Israel, J. \& Mulsow, M. Radikalaufklärung. Frankfurt am Main: Suhrkamp, 2014.

Koskinen, K. and Paloposki, O., "Retranslation". Gambier, Y. and Van Doorslaer, L. (eds.). Handbook of Translation Studies 1. Amsterdam: John Benjamins, 2010. p. 294-298.

Kozul, M. Les Lumières imaginaires. Holbach et la traduction. Oxford: Oxford Voltaire Foundation, 2016.

Lavaert, S. "Niccolò Machiavelli. The logic of conflict, against the logic of war." Philosophy of War and Peace. Praet, D. (ed.). Brussel: VUBPress, 2017. p. 105-119.

Paganini, G. Introduzione alle filosofie clandestine. Roma/Bari: Laterza, 2008.

Schröder, W. Ursprünge des Atheismus. Stuttgart-Bad Cannstatt: frommannholzboog, 2012 (particulièrement “\$8. Traité des trois imposteurs / L'esprit de Spinoza." p. 452-464).

. "Panthéisme - spinozisme - matérialisme athée. La métaphysique du

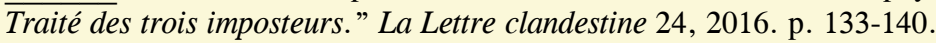


Venuti, L. "Retranslations: The Creation of Value". Bucknell Review 47 (1), 2003. p. 133-140.

Vernière, P. Spinoza et la pensée française avant la révolution. Paris: PUF, 1954 (particulièrement "Panthéisme ou matérialisme?" t. II, p. 355-375).

Vercruysse, J. "Bibliographie descriptive des éditions du Traité des trois imposteurs." Tijdschrift van de Vrije Universiteit Brussel 17, 1974/75. p. 65-70.

Recebido em: 14/08/2018

Aceito em: 20/11/18

Publicado em janeiro de 2019

Sonja Lavaert. E-mail: sonja.lavaert@vub.be

ORCID: http://orcid.org/0000-0002-8884-2338 